AGRIEKONOMIKA

http://journal.trunojoyo.ac.id/agriekonomika

Volume 9, Nomor 2, 2020

https://doi.org/10.21107/agriekonomika.v9i2.7853
Agriekonomika has been accredited as a scientific journal by the Ministry of Research-Technology and Higher Education Republic of Indonesia: No. 23/E/KPT/2019

\title{
Empowerment of Urban Farming Community to Improve Food Security in Gresik
}

\author{
${ }^{凶}$ Pawana Nur Indah, ${ }^{1}$ Indra Tjahaja Amir, ${ }^{2}$ Umar Khasan \\ Agribusiness Study Program University of Pembangunan Nasional Veteran \\ Jawa Timur, Indonesia \\ Agribusiness Master Degree Study Program University of Pembangunan Nasional \\ Veteran Jawa Timur, Indonesia
}

Received: July 2020; Accepted: October 2020; Published: October 2020

\begin{abstract}
The purpose of this study is to determine the role of urban farming community empowerment to improve food security (A case study of RT 02 and RT 03 Awikoen village, Gending-Gresik Urban Village). The method of analyzing data in this study uses Structural Equation Modeling Parial Least Square (SEM-PLS) using Smart PLS 3 application. The results of this study shows that the variable empowerment (capacity, authority, empowerment) of urban farming community members had a real influence to improve food security in Gending urban village, Gresik Regency.
\end{abstract}

Keyword: Empowerment, Urban Farming, SEM-PLS, Food Security

\section{INTRODUCTION}

Rapid population growth tends to occur in urban Indonesia. As a result, cities are not able to support the lives of some urban communities properly (Mardiansjah et al., 2018). The problems that are often faced include the availability of food, decent living facilities, especially for people with middle to lower economies. The problems of food insecurity, environmental problems such as environmental cleanliness and pollution are increasingly evident, so they need to be resolved (Fauzi et al., 2016).

Food insecurity is a condition in which families experience difficulty in fulfilling food needs (Darwis, 2013). Food insecurity is also often experienced by all levels of urban society where they depend on food supplies from outside the region (Atem \& Niko, 2020). This causes the food material to be obtained is of low quality and not fresh (Purwaningsih, 2008).

Food is the basic need (staple) apart from clothing and shelter. In addition, as long as life exists, humans still need food (Laily et al., 2014). However, the problem of food security in Indonesia can be said to be relatively lacking. Where there is an imbalance in the composition of the food group among people because rice consumption is still high, but food consumption for animals, vegetables and fruits is relatively low (Dekasari, 2016). In Law Number 18 of 2012, it describes the implementation of food. Where food administration itself is an activity of planning, implementing, and monitoring the availability, affordability and fulfillment of consumption of food and nutrition, as well as food safety while still involving the functions of the community itself (Laily et al., 2014).

Food administration in order to achieve food security can be realized through empowerment (Darwis, 2013). Empowerment is choice, free, participating in the decision-making process, cooperation and a sense of belonging to p-ISSN 2301-9948 | e-ISSN 2407-6260 
a community (Gonsalves et al., 2006). The principle of empowerment is where the community becomes the main actor in the whole series of development. In community empowerment, it is positioned as a subject to identify existing problems, participate in planning programs to create high independence (Darwis, 2013; Haris, 2014).

Efforts to build high self-reliance require the awareness of many parties, but are not limited to meeting awareness of maintaining a green environment, but are more than efforts to meet food needs with increasingly difficult economic conditions. Utilization of the potential of available resources with the concept of urban agriculture which is well known as "Urban Farming" (Sumardjo et al., 2016).

Urban farming focuses on farming, managing, and distributing food in the city boundary (Bauw, 2015; Olivier \& Heinecken, 2017; Süß, 2018). So far, the tendency for the urban farming movement to emerge in various countries is based on the food insecurity that the country has experienced (Armanda et al., 2019; Fauzi et al., 2016). In its continuation, this activity began to transform into a collective action in urban communities in Indonesia.

Gresik is an area with agricultural land, but it is a big target to be shifted to the industrial sector. Currently, Gresik Regency is one of the largest industrial estate centers in the East Java region (Shobry, 2017). Limited land in Gresik Regency area is a challenge to build awareness of food security for households. In fact, at the national level, the challenge of building food security in Indonesia is due to limited agricultural land (Muttaqin et al., 2018). On the other hand Fachriyani (2018), explained that the urban farming community in Gresik Regency has strong social capital and is in the high category. This study answers previous studies where to determine the role of urban farming community empowerment in realizing food security.

\section{METHODOLOGY}

This study is conducted in RT 02 and RT 03 Awikoen Village, Gending Urban Village, Gresik Regency. The data in this study use primary data. The primary data is obtained directly from interviews with respondents. The sampling method in this study is Non Probability Sampling. The number of samples in the study were all members of the Urban Farming community. Guidelines for determining the size of the sample size (sample size) for SEM according to Sholihin \& Ratmono (2013), that the identification of problems can be estimated using a small sample size (30-50).

\section{Data Analysis}

Quantitative data is processed using the analysis method of Structural Equation Modeling Partial Least Square (SEM-PLS) using the Smart PLS 3 application.

Where the structural equation model formulation is formulated as follows

1. The structural model equation (inner model):

$\eta_{1}=\gamma_{1} \xi_{1}+\gamma_{2} \xi_{2}+\gamma_{3} \xi_{3}+\zeta_{1}$

2. Equation of measurement model (outer model)

a. Measurement of Exogenous Variables

$X_{1}={ }_{X_{1}} \xi_{1}+{ }_{1}$

$X_{2 .}={ }_{x_{2}} \xi_{2}+$

$X_{3}={ }_{x 3} \xi_{3}+{ }_{3}$

b. Endogenous Variable Measurement

$$
\begin{aligned}
& Y_{1}={ }_{Y 1} \eta_{1}+\varepsilon_{1} \\
& Y_{2}={ }_{Y 2} \eta_{1}+\varepsilon_{2} \\
& Y_{3}={ }_{Y 3} \eta_{1}+\varepsilon_{3}
\end{aligned}
$$

Where $\eta_{1}$ is the endogenous latent variable of food security, $y$ is the coefficient of the structural equation model relationship, $\zeta$ is the error component, $\xi_{1}$ is the exogenous latent variable of capacity, $\xi_{2}$ is the exogenous latent variable of authority, $\xi_{3}$ is the exogenous latent variable of empowerment, $\mathbf{X}_{1}$ is capacity indicator variable, $\mathbf{X}_{2}$ is the authority indicator variable, $\mathbf{X}_{3}$ is the 
empowerment indicator variable, $\mathbf{Y}_{1}$ is the food availability indicator variable, $\mathbf{Y}_{\mathbf{2}}$ is the food accessibility indicator variable, $\mathbf{Y}_{3}$ is the food consumption indicator variable, $\lambda_{\mathrm{x} 1,2, \ldots \mathrm{n}}$ is the load factor of the indicator variable in latency exogenous, $\boldsymbol{\Lambda}_{\mathrm{Y} 1,2}, \ldots \mathrm{n}$ is the factor load of indicator variables on endogenous latency, and $\delta, \varepsilon$ are errors in the indicator variable relationship model (Figure 1).

\section{RESULTS AND DISCUSSION Evaluation of the Measurement Model (Outer Model)}

Evaluation of the measurement model (outer model) is carried out for each PLS scheme used, namely the path scheme, the centroid scheme, and the factor scheme. Then the evaluation of the measurement model for reflective indicators consists of assessing the results of the validity and reliability tests on each indicator against its latent variables (Aprildahani dkk., 2017; Fachriyani, 2018).

\section{Validity and Reliability Test}

In this model of study, the convergent validity test shows that the results of the analysis of the loading factor value obtained from all indicator variables have a value $(>0.5)$ and the analysis results of the Average Variance Extracted (AVE) value of the exogenous latent variables have a value of $>0.5$ (Table 1). From the discriminant validity test, the analysis results from the cross loading test show that the loading score has a higher value on its own construct, when compared to other constructs it shows that the loading score has a higher value on its own construct when compared to other exogenous latent variables.

Reliability is a coefficient value that shows the level of data consistency. A study is said to be reliable if there are similarities in data at different times. A measure that states that a variable is said to be reliable if the variable has a composite reliability $(C R)$ value that is greater than 0,7 (Fachriyani, 2018). In addition, the reliability test is strengthened by Cronbach Alpha (CA), the expected value was more than> 0.6 for all constructs (Table 2).

\section{Evaluation of the Structural Model (In- ner Model)}

The inner model aims to determine the relationship between latent variables that have been hypothesized previously. Tests are carried out to determine the value of the coefficient of determination $\left(R^{2}\right)$ for endogenous latent variables, the relevance of predictions through the procedure is calculated from the Q-square predictive relevance value, the goodness of fit (GOF) value, and the estimated path

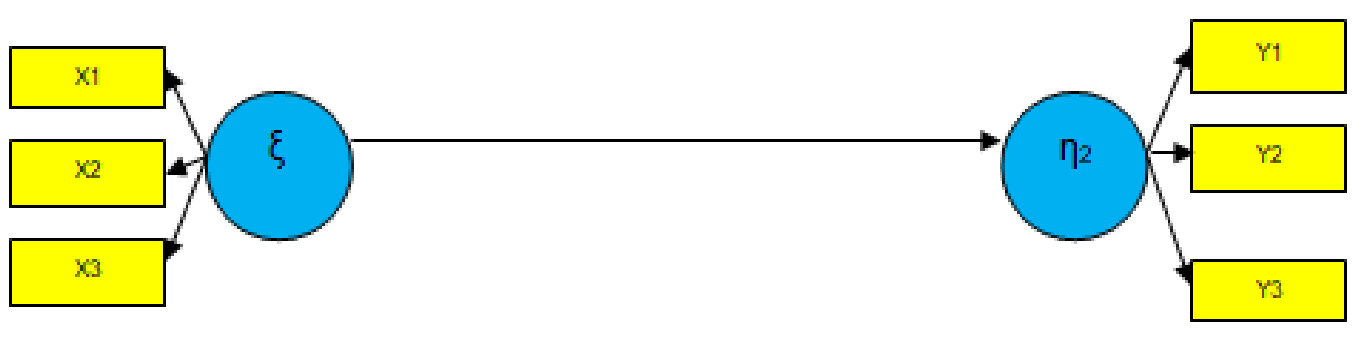

Figure 1

Model Structural Equation Modeling

Table1

Validity Test Results Based on Average Variance Extracted (AVE) Value

\begin{tabular}{ll}
\hline Variable & Average Variance Extracted (AVE) \\
\hline Empowerment of Urban Farming $(\mathrm{X})$ & 0.671 \\
Food security $(\mathrm{Y})$ & 0.674 \\
\hline
\end{tabular}

Source: Primary Data Processed, 2019 
coefficient based on the T-statistics value obtained from bootstrapping procedure in hypothesis testing (Aprildahani et al., 2017) Kabupaten Malang is one of the suburban areas. Urban sprawl is conversion of agricultural land in the suburbs. Find out about the character of farmers and set up positive mental are step that must be taken to preserve agricultural land. This study determines the influence of agricultural social, environmental, economic and policy on the farmer motivation to preserve agricultural land. The research uses statistical methods which is structural equation modeling (SEM.

Value of Determination Coefficient $\left(\mathbf{R}^{2}\right)$ The coefficient of determination $\left(R^{2}\right)$ is the value of the variance of the endogenous variable that is able to explain exogenous variables. Fachriyani (2018) explains that the endogenous latent variables in the structural model are $0.082,0.673,0.120$ indicating weak, good, and weak.

The $R^{2}$ value for the latent variable of food security is 0.999 percent, in which the variation in the food security variable can be explained by 99.9 percent, by the variation empowerment of urban farming. Meanwhile, $0.1 \%$ (percent) is influenced by other variables outside the model.

Overall, the results of the structural model analysis that illustrate the effect of urban farming empowerment on social capital (trust, normality, and social networks) in Gending Urban Village can be seen in Table 4.

\section{Analysis of the Influence Empowerment of Urban Farming Community on Food Security}

The results of the significance test show that the empowerment of urban farming community variable has a significant and significant effect on food security with the $T$ test results of $3,717>1.96$ or $0.747>0.05$. This shows that the variable empowerment of members of the urban farming community has a significant effect on food security in Gending Village, Gresik Regency (Table 5 and Table 6). It can be seen that indicators
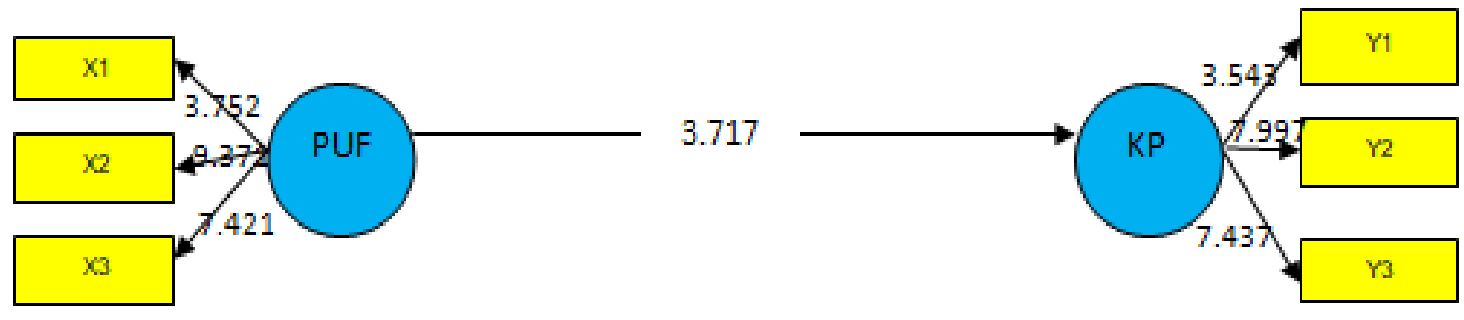

Source: Primary Data Processed, 2019

Figure 2

Loading Factor, Average Variance Extracted, dan Composite Reliability

Table 2

Reliability Test Results Based on CR and CA Values

\begin{tabular}{lll}
\hline Variable & Composite Reliability & Cronbach Alpha \\
\hline Empowerment of Urban Farming (X) & 0.858 & 0.753 \\
Food security $(\mathrm{Y})$ & 0.861 & 0.753 \\
\hline
\end{tabular}

Source: Primary Data Processed, 2019

Table 3

$\mathbf{R}^{2}$ Value of Endogenous Latent Variable

\begin{tabular}{lll}
\hline Latent variable & $\mathrm{R}^{2}$ & Criteria \\
\hline Food Security $(\mathrm{Y})$ & 0,999 & Good \\
\hline
\end{tabular}

Source: Primary Data Processed, 2019 
Table 4

Results of Model Significance Test after Respecification

\begin{tabular}{lllll}
\hline & Original Sample & Sample Mean & Standart Deviation & T-Statistics \\
\hline X1 <-- PUF & 0,719 & 0,693 & 0,192 & 3,872 \\
X2 <-- PUF & 0,789 & 0,777 & 0,091 & 8,643 \\
X3 <-- PUF & 0,935 & 0,924 & 0,119 & 7,873 \\
Y1 <-- KP & 0,774 & 0,745 & 0,218 & 3,551 \\
Y2 <-- KP & 0,751 & 0,736 & 0,100 & 7,498 \\
Y3 <-- KP & 0,929 & 0,917 & 0,118 & 7,850 \\
\hline
\end{tabular}

Source: Primary Data Processed, 2019

Table 5

Total Effect

\begin{tabular}{cc}
\hline & KP \\
\hline PUF & 0,747 \\
\hline
\end{tabular}

Source: Primary Data Processed, 2019

Table 6

Total Effect Bootstrapping

\begin{tabular}{lllll}
\hline & Original Sample & Sample Mean & Standart Deviation & T-Statistics \\
\hline PUF <-- KP & 0,747 & 0,757 & 0,201 & 3,717 \\
\hline
\end{tabular}

Source: Primary Data Processed, 2019

in empowering members of the urban farming community including capacity, authority, and empowerment have an effect of $99 \%$ in increasing food security in household members of the urban farming community in Gending Village, Gresik Regency, while $1 \%$ is influenced by other indicators outside the model (Table 3 ).

It is known that empowerment plays an important role in addition to capacity and authority in empowering urban farming communities to improve food security. High motivation from within the members of the urban farming community must be supported by facilities and infrastructure. This is because the facilities and infrastructure are the main targets of support in carrying out the empowerment of the urban farming community. The final goal is when these two factors are met, food security in household members of the urban farming community can be realized (Sumardjo et al., 2016).
Shobry (2017), explains that the urban farming program implemented by the Agricultural, Fisheries and Forestry Agency (BP4K) in Gresik Regency is running well, although it is said to be ineffective. Where the implementation process has been running and has a positive impact in its implementation. In line with Tanziha (2011), explaining where the empowerment of urban farmers can be started from the process of developing as well as strengthening the environment, and developing cooperation in the marketing division between farmer groups.

\section{CONCLUSION}

Empowerment plays an important role in addition to capacity and authority in empowering of urban farming communities to achieve food security. It can be seen that the indicators for empowering members of the urban farming community include capacity, authority, and empowerment which have an influence of $97 \%$ in 
increasing food security in household members of the urban farming community in Gending Village, Gresik Regency. This is because the facilities and infrastructure are the main targets of support in carrying out the empowerment of the urban farming community.

\section{REFERENCES}

Aprildahani, B. R., Hasyim, A. W., \& Rachmawati, T. A. (2017). Motivasi Petani Mempertahankan Lahan Pertanian di Wilayah Pinggiran Kota Malang (Studi Kasus Kawasan Perkotaan Karangploso Kabupaten Malang). Journal of Regional and Rural Development Planning, 1(3), 258-269. https://doi.org/10.29244/ jp2wd.2017.1.3.258-269

Armanda, D. T., Guinée, J. B., \& Tukker, A. (2019). The Second Green Revolution: Innovative Urban Agriculture's Contribution to Food Security and Sustainability - A review. Global Food Security, 22 (August 2018), 13-24. https://doi. org/10.1016/j.gfs.2019.08.002

Atem, A., \& Niko, N. (2020). Persoalan Kerawanan Pangan pada Masyarakat Miskin di Wilayah Perbatasan Entikong (IndonesiaMalaysia) Kalimantan Barat. Jurnal Surya Masyarakat, 2(2), 94-104.

Bauw, I. Z. (2015). Gerakan Urban Farming: Studi atas Mobilisasi Sumber Daya oleh Komunitas Bandung Berkebun [Universitas Gadjah Mada]. http:// etd.repository.ugm.ac.id/home/ detail_pencarian/84782

Darwis, V. (2013). Pelaksanaan dan manfaat kegiatan pemberdayaan masyarakat rawan pangan di DKI Jakarta. SEPA, 10(1), 88-96.
Dekasari, D. A. (2016). Pemberdayaan Petani dalam Meningkatkan Ketahanan Pangan di Desa Sambiroto, Kecamatan Padas, Kabupaten Ngawi. Jurnal Analisa Sosiologi, 5(1), 38-50.

Fachriyani, E. (2018). Pengaruh Modal Sosial terhadap Pengembangan Komunitas 'Urban Farming' di Kabupaten Gresik. Universitas Pembangunan Nasional "Veteran" Jawa Timur Surabaya.

Fauzi, A. R., Ichniarsyah, A. N., \& Agustin, H. (2016). Pertanian Perkotaan: Urgensi, Peranan, dan Praktik Terbaik. Jurnal Agroteknologi, 10(01), 49-62.

Gonsalves, J., Becker, T., Braun, A., Campilan, D., De Chavez, H., Fajber, E., Kapiriri, M., Vernooy, J., Rivaca-Caminade, R., \& (eds). (2006). Participatory Research and Development for Sustainable Agricultural and Natural Resource Management: A Resource Book (Glossary). (1st ed.). CIPUPWARDS. https://idl-bnc-idrc. dspacedirect.org/bitstream/ handle/10625/35117/IDL-35117. pdf? sequence $=1$ \&isAllowed $=y$

Haris, A. (2014). Memahami Pendekatan Pemberdayaan Masyarakat. Jupiter, 13(2), 50-62.

Laily, S. F. R., Ribawanto, H., \& Nuraini, F. (2014). Pemberdayaan Petani dalam Meningkatkan Ketahanan Pangan (Studi di Desa Betet, Kecamatan Ngronggot, Kabupaten Nganjuk). Jurnal Administrasi Publik (JAP), 2(1), 147-153. https://doi. org/10.1016/0167-5877(90)90031-C 
Mardiansjah, F. H., Handayani, W., \& Setyono, J. S. (2018). Pertumbuhan Penduduk Perkotaan dan Perkembangan Pola Distribusinya pada Kawasan Metropolitan Surakarta. Jurnal Wilayah Dan Lingkungan, 6(3), 215-233. https:// doi.org/10.14710/jwl.6.3.215-233

Muttaqin, Z., Sari, D. silvya, \& Purbasari, R. (2018). Pemanfaatan Lahan Kosong : Mengupayakan Ketahanan Pangan Global dalam Keseharian Masyarakat Lokal Di RW 12, Desa Sayang, Jatinangor, Sumedang. Prosiding Penelitian \& Pengabdian Kepada Masyarakat, 5(3), 237-250.

Olivier, D. W., \& Heinecken, L. (2017). Beyond Food Security: Women's Experiences of Urban Agriculture in Cape Town. Agriculture and Human Values, 34(3), 743-755. https://doi. org/10.1007/s10460-017-9773-0

Shobry, M. N. (2017). Faktor yang Mempengaruhi Keberhasilan Pelaksanaan Program Urban Farming di Kabupaten Gresik. Kebijaan Dan Manajemen Publik, 5(2), 1-13.
Sholihin, M., \& Ratmono, D. (2013). Analisis SEM-PLS dengan Wrap PLS 3.0 untuk Hubungan Nonlinier dalam Penelitian Sosial dan Bisnis. Andi Offset.

Sumardjo, S., Syarief, R., Riyanto, S., \& Firmansyah, A. (2016). Pemberdayaan Kemandirian Pangan Berbasis Urban Farming sebagai Alternatif Solusi Konflik Agraria dan Penanggulangan Kemiskinan. Prosiding Seminar Nasional HasilHasil PPM IPB, 264-277.

Süß, V. (2018). Role of Urban Agriculture to Increase Food Security and Economic Resilience of Refugees and Vulnerable Host Communities The case of Syrian refugees in Bourj Hammoud, Lebanon. Cologne University of Applied Sciences.

Tanziha, I. (2011). Model Pemberdayaan Petani Menuju Ketahanan Pangan Keluarga. Jurnal Gizi Dan Pangan, 6(1), 90. https://doi.org/10.25182/ jgp.2011.6.1.90-99. 